\title{
The consequences of applying a new Polish Water Law Act for protection against urban flooding
}

\author{
Ziemowit Suligowski ${ }^{1, *}$ and Nicole Nawrot ${ }^{2}$ \\ ${ }^{1,2}$ Faculty of Civil and Environmental Engineering, Gdansk University of Technology, 11/12 \\ Narutowicza Street, 80-233 Gdansk, Poland
}

\begin{abstract}
Previous legal regulations did not create conditions for a comprehensive solution to the problems of the urban melioration complex. For over 20 years, urban flooding caused by atmospheric precipitation has been systematically recurring in Poland. The article was elaborated on the experience resulting from the 2001 and 2016 floods in Gdansk (Poland). The newly adopted Water Law Act creates a foundation for a systemic solution to previously neglected issues. A new supervisory authority has been introduced as 'Polish Water' (in the Polish nomenclature: Państwowe Gospodarstwo Wodne "Wody Polskie"). The Act takes into account the problems of flood risk management and counteracting the effects of drought.
\end{abstract}

\section{Operating conditions}

There is a tendency in Polish practice to identify the problem of rainwater with its canalization. The runoff from different terrains (catchments) were automatically treated as wastewater in former legal regulations. At the same time, there was no clear system for financing their development. This approach was leading to depreciating issues related to stormwater and limiting system activities. In practice, the issue has often been identified with the "draining of roads and streets". Even an attempt to introduce standards in dealing with rainwater can be an example of underestimated problems [1]. The empirical methods for determining the amount of rainwater - traditionally used in Poland -became less and less valid as time passed [2]. Since July 1997, previously non-existent urban flooding caused by rainfall have been systematically repeated. Specific problems are caused by watercourses flowing through the cities and retention tanks. The lack of unambiguous legal regulations [3] led to the situation when it was difficult to expect solutions to the existing problems without the community's involvement as an investor. It was difficult to enforce its formal obligations from the government administration. Pomeranian floods from 2001 and 2016 are the characteristic examples of existing problems. They showed the unique significance of the complexity of undertaken activities and revealed the consequences of

\footnotetext{
* Corresponding author: ziemowit.suligowski@pg.edu.pl
} 
negligence. The rainwater drainage system in Gdańsk contains the streams which form a system of open (partially covered) collectors/ channels - Fig. 1.

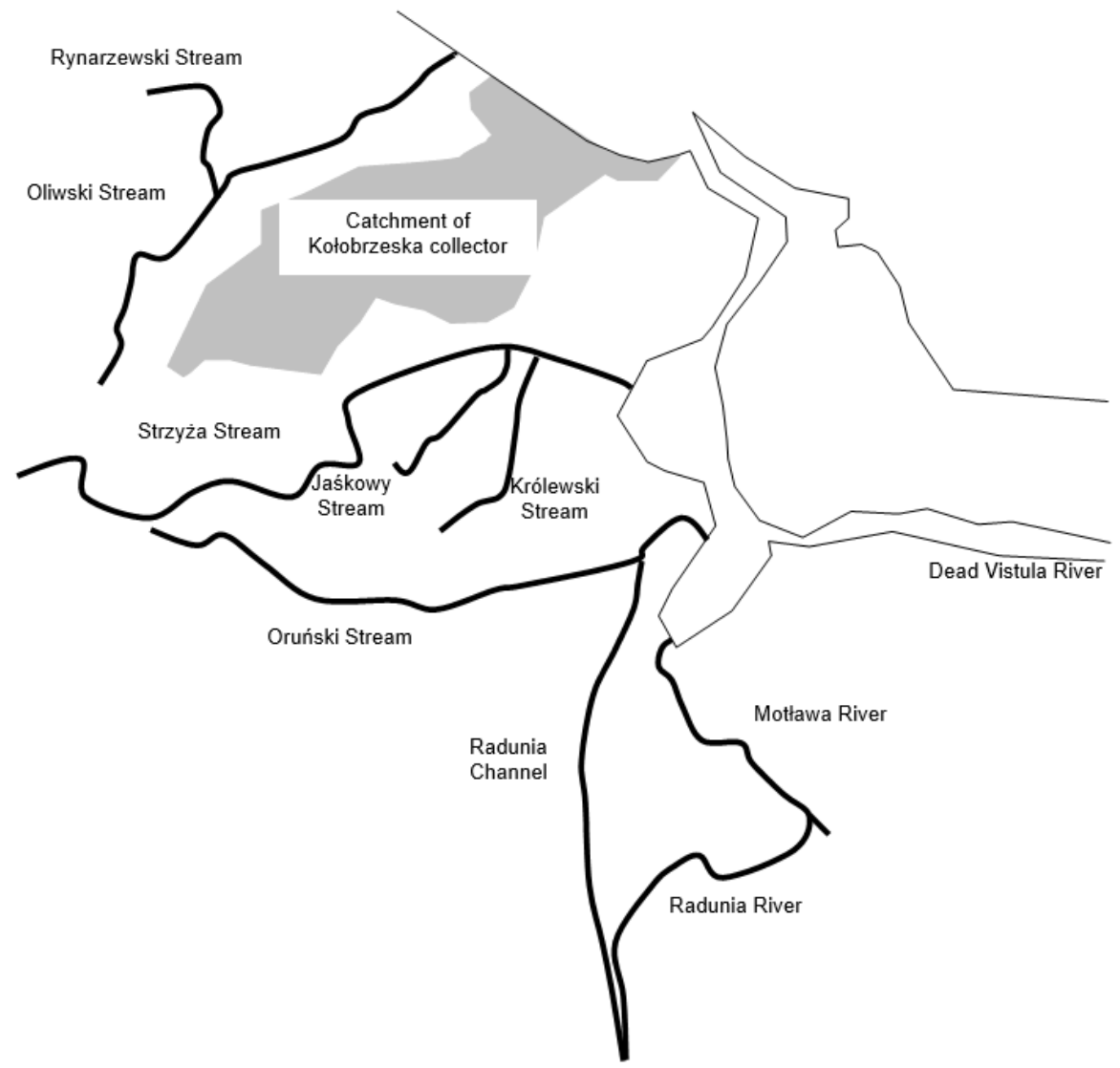

Fig. 1. Watercourses in the Gdańsk Water System.

There is only one typical urban drainage catchment that works with several rainwater pumping stations. The technical ability to drain stormwater depends on the efficiency of these pumping stations. The upper part of this catchment area is currently intensively developed. Modernization works planned in the lower part are unrealistic since potential reserves of the land have been sold. Additional problems are caused by high altitude differences. The city covers the area ranging from sea level (even depressions of the ordinates -1 below sea level) and the highland of Kashubian Lake District with the hills over $150 \mathrm{~m}$, in Gdynia even over $200 \mathrm{~m}$ ). Between both parts there is the edge zone with the terrain rapidly falling and forming relatively steep slopes (Fig. 2). In extreme cases, there is a situation of rapid changes on very short sections where there are several dozen meters of escarpment (Fig. 3). As a result, the slopes of the streams range from a few to a dozen or so, in the edge zone exceeding $20 \%$. The problem of the edge zone is particularly important, especially in the situation of impervious surface cover. For example, even the nagging but quite low precipitation ( $20 \mathrm{~mm}$, duration up to $20 \mathrm{~min}$ ), caused very serious consequences in Gdynia (2010) due to the overlap of surface runoff and caused in formation of $1 \mathrm{~m}$ high peak flow. 


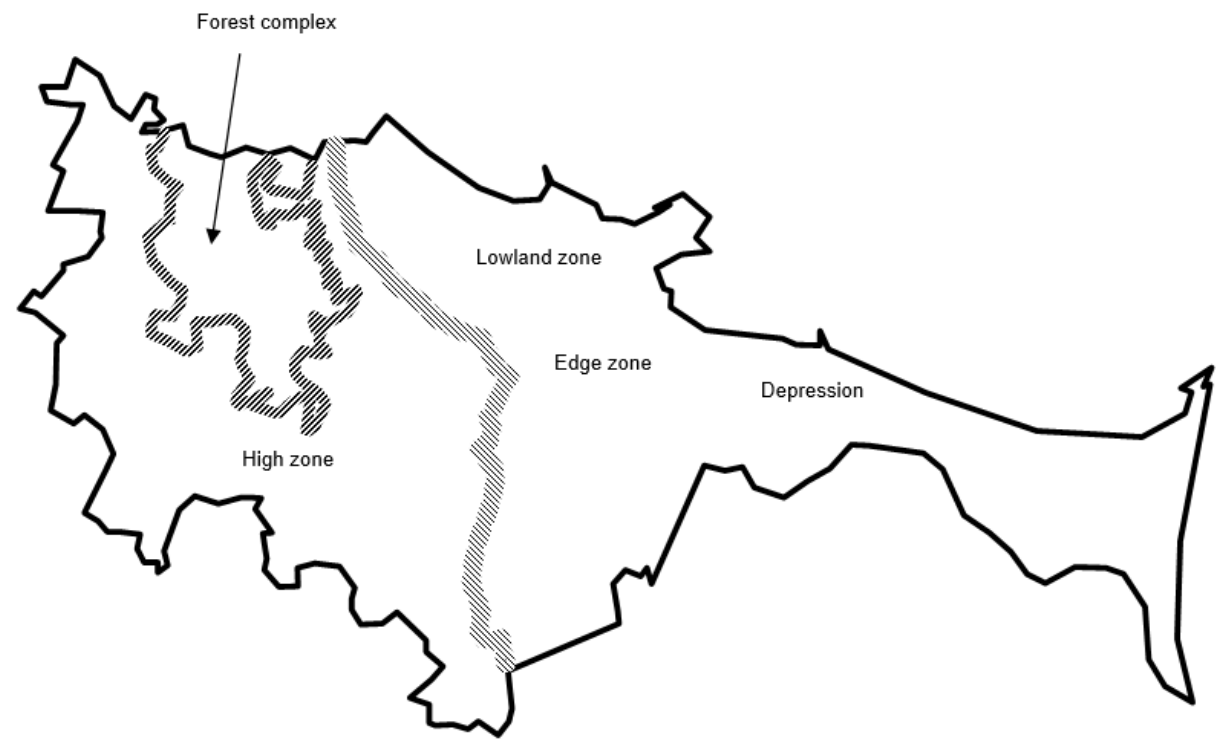

Fig. 2. Characteristic differences of height altitude in the city of Gdańsk.

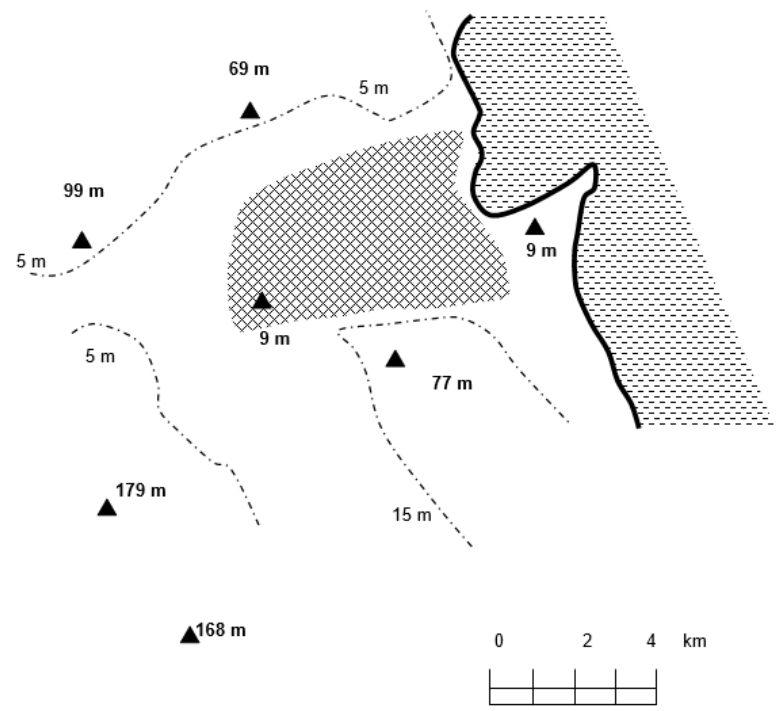

Fig. 3. Extreme altitude situations, e.g. of Gdynia.

\section{Historical floods in Gdańsk}

Although floods have happened many times in the history of Gdańsk, the characteristic caesura consists of 4 events:

- A flood in 1829: the estuary of the Vistula River was blocked due to an eastern storm, the water receded towards the city, at the same time, intense precipitation occurred and $75 \%$ of the city's area was flooded; 
- A flood in 1840: the Vistula River ceased to use the previous Wisła Śmiała riverbed segment as a result of an ice jam; in 1895 an artificial channel was made (Vistula Przekop) forming the current estuary;

- A flood in 2001: the first flood coming only from precipitation in a lower part of the city, mainly in the Radunia Channel catchment area;

- A flood in 2016: the rainfall occurred mainly in the high zone, lasted over 400 minutes with a fairly stable intensity of $40-70 \mathrm{l} /(\mathrm{s} \cdot \mathrm{ha})$.

For over 100 years, practically until 2001, the activities undertaken were dominated by events from 1829. First of all, tasks related to protection against storm backwater were implemented. At the same time, however, the transformations of the mouth of the Vistula River limited the possibility of repeating such an event as well as its possible range. However, it is virtually impossible to ensure the safety of facilities located in flooding areas. To some extent, the problem concerns about 1/3 of Poland's area. Admittedly, after 1990, several retention tanks were created, but their main task was to protect the coastal zone from pollution. In total, in the Gdańsk Water System in 2001 (December 31), there were over 20 retention tanks with a capacity of $136944 \mathrm{~m}^{3}$. Since reliable meteorological observations were missing, the city created its own network ( 9 automatic stations and 7 pluvographs) only after the flood of 2001. Due to lack of data, the flood of 1829 is better described [4] than the 2001 flood. In the consequence of the flood event from 2001, more retention tanks were built. Although the program is still under implemetation, the number of reservoirs has increased to 49, and their capacity reached $678826 \mathrm{~m}^{3}$ (five times more than in 2001). Old buildings were modernized, including former mill ponds. However, disproportions arose, the biggest efforts were made to secure the zone in which flood events were concentrated (in the catchment area of the Radunia Channel - the capacity increased fourteen times, in the Radunia River - 18 times). In other catchments, the aim was in repairing damaged facilities and organizing existing ones. As a result, the city was protected agianst a number of threats in the years 2002-2015. However, the 2016 flood event again struck the city. In contrast to previous floods, 2016 precipitation was concentrated in the highland zone. The forest complex that previously protected the city (Fig. 2) was now a source of danger. The rainfall which took place on $14 / 15^{\text {th }}$ July 2016 was exceptionally high. The analysis indicates that its probability was lower than $0.2 \%$. The amount of precipitation generating the observed runoff can be estimated at at least 190 330 , or even over $400 \mathrm{l} /(\mathrm{s} \cdot \mathrm{ha})$. Particular problems occurred in the edge zone, here as a result of overlapping surface flows it could have caused an equivalent rainfall intensity over 700 1/(s ha). In addition, high rainfall lasted not a dozen or so but several hundred minutes and its intensity was surprisingly stable. The current knowledge did not allow predicting such development of this situation and the highest precipitation occurred in the area so far relatively safe and poorly prepared. Floods and losses were unavoidable, but it remains an open question: was it possible to limit them?

The situation in Gdansk after 2001 is diversified:

- the community has been strongly involved in flood protection;

- a lot has been done, but not all problems have yet been solved;

- a flood prevention plan was created but it has not been fully implemented;

- weak points were found in the fields treated after 2001 as secondary ones;

- the insufficient area of culverts' cross-sections has been neglected;

- rescue actions were largely guided by intuition;

- retention tanks were extended, however, they were located mainly in the area endangered in 2001;

- in a number of cases the existing documentation of spatial development [5] is outdated and incomplete;

- intensive land development of dominating areas took place; 
- a stormwater drainage system (closed sewers) was preferred in plans and retention was insufficiently expanded;

- buildings are being introduced into areas that previously had natural land cover;

- a lack of preservation of the land reserve for the necessary extension of rainwater management facilities;

-a lack of compensation for retention lost as a result of the intensification of land development (a limitation of the retention capacity of previously safety areas);

- neglecting of the edge zone and location of buildings in its immediate vicinity; no reliable analysis of building project and a flood risk impact assessment;

- a weakness in supervision over implemented investments (at the same time period) and general poor coordination of investments in the city;

- many objections about the efficiency of municipal authorities can be raised, including the lack of preparation of procedures for dealing with hazardous conditions.

Generally, in Poland after 1990, the problem of spatial planning and the functioning of municipalities has not been solved. A lack of maturity at the local level resulted in the need to change legal solutions.

\section{Changes introduced by the new Water Law Act}

The Act of $20^{\text {th }}$ July 2017 on Water Law [6] changed the previous water management conditions; also in the area of cities. Premises for rainwater to be treated as a resource rather than sewage were created. In order to ensure the accomplishment of these objectives, a new institution was established: Państwowe Gospodarstwo Wodne Wody Polskie. Although its creation causes a lot of controversy, it must be taken into account that local self-governments did not work sufficiently enough. The tasks of municipalities in the field of water management, including protection against flooding, have been clearly defined. A financial instrument was introduced in the form of fees for water services. some campaigns to encourage the conservation of water resources, including financial sanctions for lost retention were taken. The subject of fees is both for the water intake as well as the discharge of sewage to water or ground and the introduction of rainwater discharged (in covered or open sewage systems) to waters. The fees also cover land drainage within the administration borders of cities and the loss of biologically active areas due to the excessive development of plots. Contemporary buildings classified as ecological often lead larger surface sealing than traditionally. The pricing system prefers to limit the drainage of rainwater, also from transportation areas. The construction of retention tanks reduces the fees for water services. The amount of reduction depends on the capacity of the tanks. This should allow not only to relieving the receivers, but also to maintaining the water balance. Regulations introduced in the Water Law Act change the existing principles of spatial planning. The agglomeration boundaries should be defined in a reasonable way in order to avoid overly dispersed infrastructural investments. This follows obligations for the discharge and treatment of sewage. Agglomerations with a population equivalent (p.e.) over 2000 should be equipped with collective collectors system directing wastewater to a sewage treatment plant. It is important to update the wastewater treatment program every four years. A number of problems that have been encountered so far have been the consequence of overly wasteful planning. Currently, the average length of the rural sewerage system in Poland is about $15 \mathrm{~m} /$ inhabitant (with a maximum recommended approx. 7 - 9 $\mathrm{m} /$ inhabitant). Limitations result from the assessment of technical and economic possibilities. It is not a coincidence that Swedish and German municipalities are not able to ensure the normal functioning of an over-developed sewage system. The construction itself is relatively simple, problems appear at the level of maintenance. 
The importance of comprehensive action in the field of flood protection is emphasized, as in the current practice the issue was treated partially. The threat must be taken into account in all phases of planning (spatial development concept, voivodship spatial development plan, voivodship development strategy, framework study of conditions and directions of spatial development of the metropolitan union, study of conditions and directions of municipal spatial development, local spatial development plan, and communal revitalization program). In contrast to the current practice, the flood hazard must be taken into account in a simplified procedure, in the decision on determining the location of the public-purpose investment and in the decision on development conditions. Although in the current legal system the above issues should be included, in practice it was completely different. Imposing the obligation to prepare appropriate documentation with precise content should exclude the current practice of reducing the problem to a few insignificant formulas. Supervision by the Wody Polskie and their participation in the creation limits the freedom of communities, but the previous solution has not worked well. As a consequence, it is difficult to overemphasize the desirability of independent verification of studies.

\section{Summary}

The existing Polish legal solutions have not been particularly effective in extreme situations. The necessity to adapt the solutions to local conditions, including the complexity of systems, requires individual solutions. The new Water Law Act creates the basis for conducting such activities. Of particular importance is a change in the approach to rainwater, which is seen in the resource category. In practice, the causes of adverse events (or at least the stimulating factor) were the mistakes made during planning of the site development. In this aspect, the importance of the comprehensive planning system described in the Act and the introduction of the control instrument must be emphasized. You can have a different point of view, but as an independent institution, Wody Polskie could have a very important role here by actively participating in planning processes. Particularly noteworthy is the complexity of the approach to the issue. Even intense activities focusing on selected elements of the system ultimately do not create conditions for achieving positive effects. In urban areas, rainwater management and flood protection create a certain whole. This problem still cannot be seen in the category of road and street drainage. This is even more important as there are no current standards/regulations in this area. The first comprehensive solution in Poland is the currently implemented retention program in the city of Bydgoszcz [2,7].

\section{References}

1. Problems of rainwater and snowmelt management. Special Notebook of Izba Gospodarcza Wodociągi Polskie. (Bydgoszcz, 2016)

2. http://www.retencja.pl [access: 1st February 2018]

3. The Water Law Act dated 18 July 2001 published in the Polish Journal of Laws January 1, 2002 (Dz.U. 2001 poz. 1121)

4. F. Wiebe, Die Reinigung und Entwässerung der Stadt Danzig. Ernst und Korn Verlag (Berlin, 1865)

5. Study of conditions and directions of spatial development of the city of Gdańsk, Urząd Miasta Gdańsk (Gdańsk, 2007)

6. The Water Law Act dated 20 July 2017 published in the Polish Journal of Laws on August 23, 2017 (Dz.U. 2017 poz. 1566)

7. http://www.bydgoska.retencja.pl [access: 1st February 2018] 